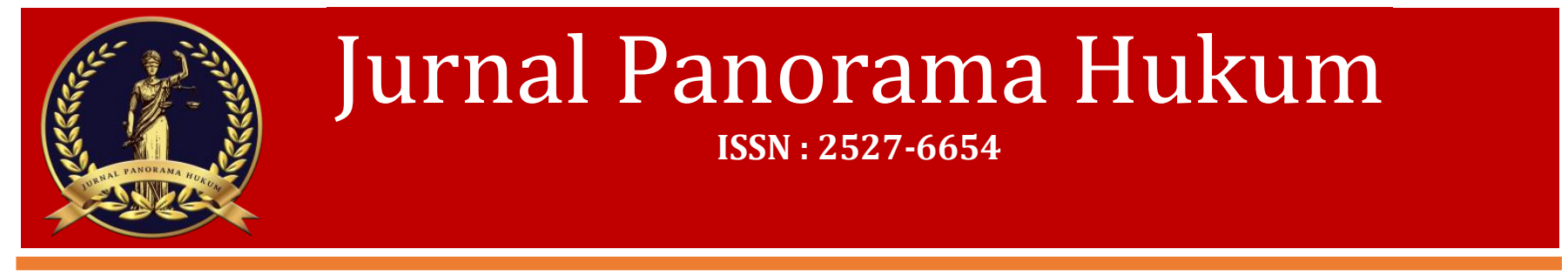

\title{
Peraturan Hukum Adat Baduy Dan Hierarki Menurut \\ Undang Undang Yang Berlaku
}

\author{
Putri Azzahra Maghfiroh* \\ Universitas Sultan Ageng Tirtayasa, Indonesia \\ azzahramaghfir02@gmail.com*
}

\begin{abstract}
The Baduy tribe is located closest to the capital city of the country. This is special to describe, how Baduy maintains its customs and customary laws in the midst of the influence of technological advances and the development of positive Indonesian law which is especially due to its geographical location not far from the metropolitan city, namely Jakarta and its surroundings. Then the purpose of this study also wants to reveal how Baduy customary law regulations and hierarchy according to applicable laws. Baduy is an ethnic indigenous people who still live in Indonesia. The hierarchy or order of laws and regulations in Indonesia refers to the recognition and respect given by the state in Article 18B paragraph (2) of the 1945 Constitution of the Republic of Indonesia, which is not sufficient to protect the rights of the Baduy customary law community plus the weakness of Perda No.32 of 2001 which discuss the customary rights of the Baduy customary community only. The clash of Baduy traditional interests with the government system has made Baduy weaker in terms of representation. The government must immediately draft a law related to the protection of Baduy customary rights and or create a representation mechanism for indigenous peoples
\end{abstract}

Key Words: Customary Law; Adat Baduy; Hierarchy or Order of Legislation

\begin{abstract}
Abstrak: Suku Baduy terletak paling dekat dengan ibu kota negara. Hal ini khusus untuk menggambarkan, bagaimana Baduy mempertahankan adat dan hukum adatnya di tengah pengaruh kemajuan teknologi dan perkembangan hukum positif Indonesia yang terutama karena letak geografisnya yang tidak jauh dari kota metropolitan yaitu Jakarta dan sekitarnya. Adapun tujuan dari penelitian ini juga ingin mengungkap bagaimana peraturan dan hierarki hukum adat Baduy menurut hukum yang berlaku. Baduy merupakan suku bangsa asli yang masih hidup di Indonesia. Hirarki atau tatanan peraturan perundangundangan di Indonesia mengacu pada pengakuan dan penghormatan yang diberikan oleh negara dalam Pasal 18B ayat (2) Undang-Undang Dasar Negara Republik Indonesia Tahun 1945, yang tidak cukup untuk melindungi hak-hak hukum adat Baduy. masyarakat ditambah kelemahan Perda No.32 Tahun 2001 yang hanya membahas tentang hak ulayat masyarakat adat Baduy saja. Benturan kepentingan adat Baduy dengan sistem pemerintahan membuat Baduy semakin lemah dalam hal keterwakilan. Pemerintah harus segera menyusun undang-undang terkait perlindungan hak adat Baduy dan atau membuat mekanisme perwakilan masyarakat adat
\end{abstract}

Kata kunci: Letakkan 3-5 kata kunci Anda di sini; kata kunci dipisahkan dengan tanda titik koma

\section{Pendahuluan}

Istilah hukum adat pertama sekali diperkenalkan oleh Snouck Hurgronje pada Tahun 1983 dalam bukunya De Atjehnese. ${ }^{1}$ Dalam buku itu dia memperkenalkan istilah Adatrecht (hukum adat) yaitu hukum yang berlaku bagi bumi putra (orang Indonesia asli) dan orang

${ }^{1} 1$ Djuned T. (1992). Asas-asas Hukum Adat, Fakultas Hukum Unsyiah, p.8. 
timur asing pada masa Hindia Belanda. Hukum adat baru mempunyai pengertian secara tehnis yuridis setelah C. Van Vollenhoven mengeluarkan bukunya yang berjudul Adatrecht. Dialah yang pertama sekali menyatakan bahwa hukum adat merupakan hukum yang berlaku bagi rakyat Indonesia asli dan mejadikannya sebagai objek ilmu pengetahuan hukum positif serta dijadikan sebagai mata kuliah tersendiri. Dia juga yang mengangkat hukum adat sebagai hukum yang harus diterapkan oleh hakim gubernemen. ${ }^{2}$

Diantara beragam hukum adat yang tersebar di Indonesia, hukum adat Baduy adalah salah satu hukum adat yang ada di Indonesia dan berlaku mengatur masyarakat adat Baduy selama ratusan tahun dari generasi ke generasi. Bahkan hingga kini hukum adat Baduy masih berlaku mengikat bagi masyarakat adat Baduy. Baduy adalah sebuah komunitas masyarakat terasing ${ }^{3}$ di Desa Kanekes Kecamatan Leuwidamar Kabupaten Lebak, Banten. Sebagaimana masyarakat adat pada umumnya, merekapun memiliki hukum adat sendiri yang berlaku mengikat pada masing-masing anggota masyarakatnya, termasuk hukum pidana adat, yang merupakan subsistem dari hukum adat Baduy.

\section{Metode}

Jenis penelitian yang digunakan dalam penelitian ini adalah deskriptif kualitatif merupakan sebuah metode penelitian yang memanfaatkan data kualitatif dan dijabarkan secara deskriptif. Tujuannya untuk mengetahui peraturan hukum adat baduy dan hierarki menurut undang undang yang berlaku. Sedangkan Sumber data merupakan asal dari data yang telah diperoleh. Dalam penelitian ini terdapat sumber data sekunder adalah data yang didapat secara tidak langsung melalui sumber sekunder. Data sekunder dalam penelitian ini adalah literatur kepustakaan berupa jurnal, artikel, hasil penelitian yang menjadi referensi, dan buku-buku penunjang yang berkaitan dengan penelitian ini.

\section{Hasil dan Pembahasan}

\section{Urgensi Kajian Hukum Adat}

Kusumadi Pudjosewojo memberikan pengertian hukum adat adalah "keseluruhan aturan hukum yang tidak tertulis". ${ }^{4}$ Pengertian tersebut hampir sama dengan pengertian yang dikemukakan oleh Soepomo yang menyatakan "hukum adat adalah synonim dari "hukum tak tertulis" Hukum yang tidak tertulis berarti hukum yang tidak dibentuk oleh badan legislatif. Lebih jauh Kusumadi menjelaskan bahwa hukum adat bukan merupakan lapangan hukum

\footnotetext{
p. 64.

${ }^{2}$ Pudjosewojo, Kusumadi. (1976). Pedoman Pelajaran Tata Hukum Indonesia, Jakarta: Aksara Baru.

${ }^{3}$ Suhada menuliskan penggunaan istilah masyarakat terasing bagi masyarakat Baduy adalah keliru. Masyarakat terasing didefinisikan Departemen Sosial sebagai masyarakat yang terisolasi dan memiliki kemampuan terbatas untuk berkomunikasi dengan masyarakat-masyarakat lain yang lebih maju, sehingga karena itu bersifat terbelakang serta tertinggal dengan proses mengembangkan kehidupan ekonomi, politik, sosial budaya, keagaman dan ideologi. Masyarakat Baduy, menurut Suhada lebih tepat dikatakan sebagai masyarakat yang mengasingkan diri. Masyarakat Baduy menjalin intensitas komunikasi dengan masyarakat luar melalui kunjungan. Mereka memiliki sistem sendiri dalam pemenuhan sandang, pangan dan papan sehari-hari yang telah dijalani lama turun temurun. Mereka memilih hidup dengan memegang teguh hukum adat yang mereka miliki. Lihat dalam Suhada. Masyarakat Baduy dalam Rentang Sejarah. Dinas Pendidikan Propinsi Banten. 2003. p16. $\mathrm{p}, 42$.

${ }^{4}$ Pudjosewojo, Kusumadi . (1976). Pedoman Pelajaran Tata Hukum Indonesia, Jakarta: Aksara Baru,
} 
tersendiri melainkan meliputi semua lapangan hukum. Dengan demikian terdapat hukum tatanegara adat, hukum perdata adat, hukum dagang adat, hukum pidana adat dan lain sebagainya. Berdasarkan pengertian atau difinisi yang dikemukakan di atas ada tiga ciri khusus yang membedakan hukum adat dengan hukum lain yaitu berlaku untuk orang Indonesia, tidak tertulis dan tidak dibuat oleh badan legislative. Berartinya penggalian hukum adat sebelumnya sempat diingatkan oleh Cornelis Van Vollenhoven dalam mengakhiri bukunya yang bertajuk penemuan hukum adat. Jadi tugas untuk melanjutkan penemuan hukum adat, eksklusifnya menimpa orang Indonesia untuk sementara waktu wajib ditanggung oleh mereka( orang Indonesia) yang bertempat tinggal di Hindia Belanda. Perihal ini masuk akal, bukan saja mereka ialah 49.000. 000 dari 66. 000. 000 yang mendiami daerah Indonesia dari Formosa hingga Madagascar, namun pekerjaan pendahuluan sebagian besar telah dilakukan. Papan untuk meloncat sudah tersedia untuk mereka. ${ }^{5}$ Barda Nawawi Arief dalam pidato pengukuhan guru besarnya melaporkan bahwa penggalian serta pengembangan nilai- nilai hukum pidana yang hidup di dalam warga bertumpu pada dunia akademik/ keilmuan. Barda Nawawi Arief menyebut nilai- nilai hukum yang hidup dalam warga bagaikan" batang terandam" yang belum banyak terangkat ke permukaan. Upaya mengangkut batang terandam ini berarti dicoba buat dikaji secara mendalam selaku bahan penataan hukum nasional. ${ }^{6}$

\section{Adat, Hukum Adat dan Hukum Kebiasaan (Customary Law).}

Pertama, Adat. Dalam beberapa literatur, terminologi adat ditengarai berasal dari kata Adah yang dalam bahasa Arab merujuk pada ragam perbuatan yang dilakukan secara berulang-ulang. ${ }^{7}$ Ragam perbuatan yang dilakukan secara berulang-ulang tersebut kemudian yang menjadikan peristilahan Adat sering diasosiasikan dengan kebiasaan. Maka adat kemudian diartikan sebagai perilaku masyarakat yang bersifat ajeg, selalu dikerjakan atau perilaku masyarakat yang selalu dilakukan atau dengan kata lain bahwa kebiasaan adalah perilaku masyarakat (anggota-anggota masyarakat secara bersama-sama) yang ajeg atau yang selalu dikerjakan, dan oleh karena itu bersifat wajib. ${ }^{8}$ I Gede AB Wiranata membagikan penegasan arti yang lebih atas penafsiran adat. Baginya adat dimaksud bagaikan kebiasaan yang menurut anggapan masyarakat sudah tercipta, baik saat sebelum ataupun setelah terdapatnya masyarakat. ${ }^{9}$

Kedua, Hukum Adat. Sebagaimana halnya dengan Adat, kata Hukum juga berasal dari bahasa Arab hukm, bentuk jamaknya ahkam yang berarti perintah, suruhan atau ketentuan. ${ }^{10}$ Cristian Snouck Hurgronje adalah ahli hukum yang mengenalkan istilah hukum adat (Adatrecht). Hurgronje menggunakan istilah hukum adat pertama kalinya dalam buku De Aceher's (Orangorang Aceh) tahun 1894. Istilah hukum adat digunakannya untuk

\footnotetext{
${ }^{5}$ Vollenhoven, Cornelis Van. (1981). Penemuan Hukum Adat (De ontdekking van het adatrecht). Terjemahan Koninklijk Instituut voor Taal-, Land-en Volkenkunde (KITLV) bersama Lembaga Ilmu Pengetahuan Indonesia (LIPI). Jakarta. Jambatan. p.160

${ }^{6}$ Arief. Barda Nawawi. (2007). Beberapa Aspek Pengembangan Ilmu Hukum Pidana (Menyongsong Generasi Baru Hukum Pidana Indonesia). Semarang: Badan Penerbit Undip. p.50.

${ }^{7}$ Wiranata, I Gede AB . (2005). Hukum Adat Indonesia, Perkembangnya dari Masa ke Masa. Bandung: Citra Aditya Bakti. p.3.

8 Rato, Dominikus. (2009). Pengantar Hukum Adat. Yogyakarta: LaksBang Pressindo. p.5.

9 opcit

${ }^{10}$ Rato, Dominikus. (2009). Pengantar Hukum Adat. Yogyakarta: LaksBang Pressindo. p. 4.
} 
menyebut sistem pengendalian sosial (social control) yang bersanksi (disebut hukum adat), yang dibedakan dengan istilah adat sebagai sistem pengendali sosial lain yang tidak memiliki sanksi. $^{11}$

Ketiga, Hukum Kebiasaan (Customary Law). Penyamaan hukum adat dan hukum kebiasaan ini tidak dapat diterima semua pihak. Salah satu tokoh yang berkeberatan berkaitan hal ini adalah Van Dijk:

"Tidaklah tepat menerjemahkan adatrecht menjadi hukum kebiasaan untuk menggantikan hukum adat, oleh karena yang dimaksud dengan hukum kebiasaan adalah "kompleks peraturan-peraturan hukum yang timbul karena kebiasaan", artinya karena telah demikian lamanya orang biasa bertingkahlaku menurut suatu cara tertentu sehingga timbulah suatu peraturan kelakuan yang diterima dan juga yang diinginkan masyarakat, sedang apabila orang mencari sumber yang nyata dari mana peraturan itu berasal, hampir senantiasa akan ditemukan suatu alat perlengkapan masyarakat tertentu dalam lingkungan besar atau kecil sebagai pangkalnya."

Blackes Law Dictionary, mengartikan customary law (hukum kebiasaan) sebagai berikut:" "Law consisting of customs that are accepted as legal requirement or obligatory rules of conduct; dan Practise and beliefs that are so vital and intrinsic a part of a social and economic system that they are treated as if they were laws."

Mencermati uraian di atas, pada dasarnya customary law adalah hukum yang bersumber dari kebiasaan yang kemudian diterima sebagai kebutuhan hukum atau kewajiban dalam bertingkah laku. Jadi senada dengan Van Dijk, customary law memiliki penekanan yang lebih pada kebiasaan yang berulang sehingga menjadi sebuah hukum, sementara pada hukum adat meskipun terdapat unsur kebiasaan namun berpangkal pada suatu pranata masyarakat yang memiliki otoritas untuk menetapkannya sebagai sebuah hukum. Meskipun kemudian hukum adat sering diterjemahkan menjadi customary law dan banyak penulis secara sederhana menyamakannya namun perbedaan mendasar antara keduanya perlu diketahui. Sebagaimana Roelof H Haveman yang menggunakan istilah customary law untuk menerjemahkan hukum adat, namun lebih lanjut Haveman menjelaskan perbedaan keduanya. Dalam bukunya Ia menuliskan: Adat law is customary law. More specifically: adat law is a type of customary law. ${ }^{13}$ Jadi meskipun Haveman menyatakan hukum adat adalah hukum kebiasaan/customary law, namun lebih lanjut Haveman menegaskan bahwa hukum adat adalah salah satu jenis hukum kebiasaan/ customary law. Pemahaman Haveman tersebut selaras dengan pendapat Van Vollenhoven. Bagi Van Vollenhoven, hukum adat merupakan perihal lain dari pada hukum kebiasaan(gewoontenrecht) karena tercantum sebagai sumbersumbernya yaitu: peraturan-peraturan desa, peraturan-peraturan dari raja-raja bumi putra, serta peraturan-peraturan fiqh. ${ }^{14}$

${ }^{11}$ Wiranata, I Gede AB. (2005). Hukum Adat Indonesia, Perkembangnya dari Masa ke Masa. Bandung. Citra Aditya Bakti. p.9.

${ }^{12}$ Garner, Bryan A. (1999). Black's Law Dictionary (seventh edition). ST.Paul Minn. p.391.

${ }^{13}$ Haveman, Roelof H. .(2002).The Legality of Adat Criminal Law in Modern Indonesia. Jakarta: Tatanusa. p.5.

${ }^{14}$ Djojodiguno tidak sependapat dengan Van Vollenhoven, menurutnya penyebutan peraturan desa dan peraturan raja ke dalam bilangan hukum adat adalah keliru, sebab menurutnya kedua hal tersebut adalah 


\section{Asas Legalitas Materil dan Kedudukannya dalam Peraturan Perundang-undangan.}

Selain pengakuan asas legalitas materil dalam ajaran hukum pidana. Kedudukan legalitas materil sebenarnya juga telah diakui keberadaan dan keberlaku annya pasca kemerdekaan Indonesia dalam peraturan perundang-undangan. Berbagai ketentuan peraturan perundang-undangan menjelaskan bahwa kedudukan asas legalitas materil dalam peraturan perundang-undangan diakui keberadaan dan keberlakuannya. Terlebih dalam pasal 24 (amandemen ke-3) UUD 1945 ditegaskan bahwa kekuasaan kehakiman merupakan kekuasaan yang merdeka untuk menyelenggarakan peradilan guna menegakan hukum dan keadilan. Maka pada hakikatnya peradilan diselenggarakan untuk menegakan hukum (recht/ius) dan keadilan, bukan menegakan hukum secara sempit yang sering direduksi menjadi undang-undang (wet/lege). Hukum memiliki makna yang lebih luas dari undang undang, sebab hukum berarti meliputi hukum yang tertulis dan hukum yang tidak tertulis.

\section{Hukum Adat dalam Konsep KUHP}

Sebagaimana diketahui, dalam Seminar Hukum Nasional I Tahun 1963, direkomendasikan agar rancangan kodifikasi hukum pidana nasional selekas mungkin diselesaikan. Maka tahun 1964 dibicarakan konsep KUHP yang pertama. Berturut-turut kemudian ada pula konsep 1971/1972, Konsep 1982/1983 yang kemudian menjadi konsep 1987/1988, Konsep 1991/1992, Konsep 1997/1998 Konsep 2004 sampai dengan 2006/2007. . $^{15}$

Asas legalitas dalam Konsep KUHP ditempatkan dalam Buku Kesatu Ketentuan Umum. ${ }^{16}$ Sama halnya dengan KUHP, asas legalitas dalam Konsep KUHP juga dirumuskan dalam pasal $1 .{ }^{17}$ Dalam penerapannya, pidana tambahan tersebut (termasuk point e tentang hukum adat/hukum yang hidup) dapat dijatuhkan bersama-sama dengan pidana pokok, sebagai pidana yang berdiri sendiri atau dapat dijatuhkan dengan pidana tambahan lainnya. ${ }^{18}$ Selanjutnya dalam pasal 67 ayat (3), ditegaskan bahwa pemenuhan kewajiban adat atau hukum yang hidup juga dapat dijatuhkan terhadap korporasi meskipun tidak tercantum dalam perumusan tindak pidana. ${ }^{19}$

termasuk kedalam hukum peraturan. Lihat lebih lanjut dalam I Gusti Ketut Sutha. Bunga Rampai Beberapa Aspekta Hukum Adat. Yogyakarta: Liberty.1987.p.11.

15 Arif, Barda N . (2008). Bunga Rampai Kebijakan Hukum Pidana Perkembangan Penyusunan Konsep KUHP Baru. Jakarta: Kencana Prenada Media. P. 96.

${ }^{16}$ Kecuali Konsep KUHP awal, Konsep KUHP hanya membagi KUHP ke dalam dua buku: Ketentuan Umum (Buku I) dan Tindak Pidana (Buku II).

${ }^{17}$ Pada konsep 1997/1998 asas legalitas ditempatkan dalam pasal 2, hal ini disebabkan pengertianpengertian yang bersifat umum ditempatkan dalam pasal 1 .

18 Pasal 67 ayat 2 Konsep KUHP 2006.

${ }^{19}$ Perumusan ini mengakomodir keresahan masyarakat hukum adat selama ini yang seringkali harus berhadapan dengan korporasi yang menggunakan hukum formal dalam kehidupan sehari-hari. Biasanya terjadi dalam kasus sengketa tanah adat yang dirambah. Seperti yang dialami oleh Loir Botor Dingit, Kepala Suku Dayak Bentian Jato Rempangan Jelmu Sibak, Kecamatan Bentian, Kabupaten Kutai, Kalimantan Timur yang harus menghadapi PT Kalhold Utama milik Bob Hasan yang menggusur tanah adat, tanaman dan makam leluhur Jelmu Sibak. Lihat lebih lanjut dalam Loir Botor Dingit. Kasus Sengketa Tanah Adat di Jelmu Sibak, Pertarungan Hukum Adat versus Hukum Formal dalam Sandra Kartika dan Candra Gautama. (1999). Menggugat Posisi Masyarakat Adat Terhadap Negara. Prosiding Sarasehan Masyarakat Adat Nusantara, Jakarta 15-16 Maret 1999. Yogyakarta: Pustaka Pelajar. p. 7. 


\section{Asal Usul Baduy}

Secara geografis lokasi masyarakat Baduy terletak pada $6^{\circ} 27^{\prime} 27^{\prime \prime}-6^{\circ} 30^{\prime}$ Lintang Utara (LU) dan 108³'9"1064'55" Bujur Timur (BT). Masyarakat Baduy berada pada wilayah bagian barat Pulau Jawa, pada daerah yang merupakan bagian dari pegunungan Kendeng (900 mdpl). Secara administratif masyarakat Baduy tinggal di Desa Kanekes Kecamatan Leuwidamar Kabupaten Lebak Propinsi Banten.

Menurut Jaro Dainah, Kepala Desa Kanekes, Desa Kanekes terdiri dari 59 kampung yang terdiri dari tiga kampung Baduy Dalam, 55 kampung Baduy Luar dan satu kampung luar Baduy. Jumlah kampung Baduy Dalam tidak akan mengalami perubahan hingga kapanpun, selalu berjumlah tiga (Cibeo, Cikartawana, Cikeusik). Sementara jumlah kampung Baduy Luar dapat berubah sesuai dengan pemekaran wilayah. Satu kampung yang disebut Jaro Dainah sebagai luar Baduy adalah Cicakal Girang. Cicakal Girang tidak dikategorikan sebagai Baduy Luar karena kebanyakan warga Cicakal Girang mulai menjadi pemeluk agama Islam, sementara warga Baduy Dalam dan Baduy Luar adalah pemeluk agama Sunda Wiwitan.

\section{Perbedaan Baduy Dalam dan Baduy Luar.}

Baduy Dalam memiliki berbagai ciri dan aturan yang berbeda dengan Baduy Luar. Namun secara prinsipil perbedaan mereka terletak pada ketat longgarnya aturan adat yang harus mereka jalani. Masyarakat Baduy Dalam memiliki aturan adat yang lebih ketat dibandingkan masyarakat Baduy Luar. Namun demikian, dalam konsep hukum adat Baduy, keduanya memiliki perannya masingmasing. Menurut Jaro Dainah, masyarakat Baduy Dalam berkewajiban dalam hal bertapa. Tapa yang dimaksud bukan diartikan sebagai bersemedi, namun tapa dalam pengertian meneguhkan/melestarikan adat Baduy, meneguhkan agama sunda wiwitan. Sementara masyarakat Baduy Luar bertugas sebagai panamping, untuk menjaga masyarakat Baduy Dalam yang sedang bertapa, sehingga turut juga membantu meneguhkan adat.

Karena perbedaan prinsipil tersebut maka Baduy Dalam memiliki aturan yang lebih ketat dalam menjalankan hukum adat dan melestarikan adat Baduy, sementara Baduy Luar memiliki aturan yang lebih longgar namun memiliki konsekwensi untuk turut membantu Baduy Dalam dalam hal melestarikan adat. Pada prinsipnya larangan-larangan pada masyarakat Baduy dilandaskan pada filosofi dasar Baduy, lojor teu meunang dipotong, pondok teu meunang disambung (panjang tak boleh dipotong, pendek tak boleh disambung). Menurut Jaro Dainah, konsep dasar ajaran di Baduy tersebut adalah keseimbangan alam, kelestarian alam, maka dengan demikian Baduy mempunyai kewajiban untuk melestarikan alam dan tidak menentang hukum alam.

\section{Hierarki Hukum Adat Menurut Undang Undang yang Berlaku}

Sebagaimana sudah dijelaskan di atas bahwa hukum dan hukum adat mempunyai arti yang sama yaitu sebagai suatu rangkaian norma yang mengatur tingkah laku dan perbuatan dalam hidup bermasyarakat dengan tujuan terciptanya suatu ketertiban dalam masyarakat. Yang membedakannya adalah hukum adat berlaku bagi orang Indonesia, sifatnya tidak tertulis dan tidak dibuat oleh legislatif. 
Dalam pemberlakuan hukum adat sebagai hukum positif kiranya perlu diketengahkan dua konsep pemikiran tentang hukum yang sangat tajam mempertentangkan kedudukan hukum adat dalam sistem hukum yaitu konsep pemikiran legisme (termasuk aliran positivisme) dan aliran mazhab sejarah. Aliran legisme menghendaki bahwa pembuatan hukum dapat begitu saja dilakukan dengan undang-undang, sedangkan aliran sejarah menentang penyamaan hukum dengan undang-undang sebab hukum itu tidakmungkin dibuat melainkan harus tumbuh dari kesadaran hukum masyarakat.

Aliran mazhab sejarah yang dipelopori Von Savigny cukup besar pengaruhnya dalam membentuk aliran tentang pembangunan hukum di Indonesia yang pada awalnya juga terbelah atas aliran yang menghendaki kodifikasi dan unifikasi serta aliran yang menghendaki dipertahankannya hukum adat yang tidak dikodifikasi dan tidak diunifikasikan. Aliran mazhab sejarah menghendaki agar hukum adat yang merupakan pencerminan nilainilai kebudayaan asli Indonesia dipertahankan untuk mencegah terjadinya pembaratan dalam hukum. Pada sisi lain mempertahankan hukum adat juga berimplikasi negatif yaitu terisolisasinya bangsa Indonesia dalam perkembangan hukum modern sehingga mengakibatkan keterbelakangan dan menimbulkan problem terutama dalam bersaing dengan bangsa lain.

Pertentangan di atas tidak perlu dipertahankan melainkan harus dipertemukan dalam keseimbangan antara hukum sebagai alat dan hukum sebagai cermi budaya masyarakat. Juga antara hukum sebagai alat untuk menegakkan ketertiban yang sifatnya konserfatif (memelihara) dan hukum sebagai alat untuk membangun (mengarahkan) masyarakat agar lebih maju. Konsep ini sangat sesuai dengan pemikiran yang disampaikan oleh EugenEhrlich yang dikenal dengan aliran sociological jurisprudence yang berbicara tentang living law atau hukum yang hidup dalam masyarakat. Menurut Ehrlich bahwa hukum positif yang baik dan efektif adalah hukum yang sesuai dengan living law yaitu yang mencerminkan nilai-nilai yang hidup dalam masyarakat.

Dalam Pembukaan Undang-Undang Dasar Negara Republik Indonesia Tahun 1945, Tujuan Nasional Negara Republik Indonesia tertuang dalam Alinea Keempat, disebutkan bahwa "...Melindungi segenap bangsa indoenesia dan seluruh tumpah darah Indonesia dan untuk Memajukan kesejahteraan umum, Mencerdaskan kehidupan bangsa, dan Ikut melaksanakan ketertiban dunia yang berdasarkan kemerdekaan, perdamaian abadi dan keadilan sosial...". Dimana jika dikaitkan dengan aturan hukum adat yang berlaku di lingkungan masyarakat adat baduy menjadi kontras tersirat bahwa beberapa hukum adat baduy dapat bertentangan dengan cita-cita bangsa Indonesia tersebut.

Hukum dalam pengertian luas dapat dikelompokkan dalam dua bagian yaitu hukum tertulis dan hukum tidak tertulis. Hukum adat termasuk dalam kelompok kedua. Akan tetapi yang menjadi permasalahan adalah tidak ada satu pasalpun dalam batang tubuh UndangUndang Dasar UUD) 1945 yang mengatur tentangkedudukan hukum tidak tertulis. Malah pasal-pasal dalam batang tubuh UUD 1945 banyak yang memerintahkan ketentuan pasalnya untuk diatur lebih lanjut dengan Undang-undang (undang-undang oeganik). Perintah pengaturan lebih lanjut ketentuan Pasal dalam UUD 1945 ke dalam undang-undang mengandung makna bahwa Negara Indonesia lebih mengutamakan hukum yang tertulis.

Pengakuan terhadap hukum tidak tertulis dahulu hanya dijelaskan atau dicantumkan dalam Penjelasan Umum UUD 1945 angak I yang menyebutkan ”... Undang-Undang Dasar 
ialah hukum dasar yang tertulis, sedang di sampingnya Undang-undang Dasar itu berlakunya juga hukum dasar yang tidak tertulis, ialah aturan-atauran dasar yang timbul dan terpelihara dalam praktik penyelenggaraan negara meskipun tidak tertulis".

Dalam Pasal 18B ayat (2) Amandemen UUD 1945 menyebutkan "Negara mengakui dan menghormati kesatuan-kesatuan masyarakat hukum adat beserta hak-hak tradisionalnya sepanjang masih hidup dan sesuai dengan perkembangan masyarakat dan prinsip Negara Kesatuan Republik Indonesia, yang diatur dalam undang-undang”. Menurut pasal ini hukum adat yang diakui adalah hukum adat yang masih nyata-nyata hidup, jelas materi dan lingkup masyarakat adatnya.

Ketentuan Pasal 18b ayat (2) di atas dapat dipahami bahwa UUD 1945 lebih mengutamakan hukum yang tertulis dari pada tidak tertulis. Ini maknanya bahwa pengakuan terhadap hukum adat yang masih hidup dalam masyarakat di suatu daerah harus dilakukan dengan pengaturan dalam peraturan perundang-undangan (tertulis). Untuk menganalisa kedudukan hukum adat dalam sistem hukum perlu kiranya diperhatikan salah satu aliran dalam ilmu hukum yaitu, Sociological Jurisprudence yang disampaikan oleh Eugen Ehrlich. Yang menjadi konsepsi dasar dari pemikiran Ehrlich tentang hukum adalah apa yang dinamakan dengan living law. Hukum positif yang baik dan efektif adalah hukum yang sesuai dengan living law dari masyarakat yang mencerminkan nilai-nilai yang hidup di dalamnya.

\section{Kesimpulan}

Berdasarkan analisis di atas dapat disimpulkan bahwa Kedudukan hukum adat dalam sistem hukum sama dengan kedudukan hukum pada umumnya, yang membedakannya adalah hukum adat hanya berlaku untuk orang Indonesia dan sifatnya tidak tertulis. UUD 1945 sebagai konstitusi mengakui di samping hukum tertulis juga ada hukum yang tidak tertulis, hukum adat merupakan hukum tidak tertulis. Hierarki atau tata urutan peraturan perundang-undangan di Indonesia pada pengakuan dan penghormatan yang diberikan oleh negara tidak cukup untuk melindungi hak-hak masyarakat hukum adat Baduy ditambah lemahnya Perda Baduy semakin lemah dalam hal keterwakilan karena terbenturnya kepentingan adat Baduy dengan sistem pemerintahan.

\section{Daftar Rujukan}

Arif, Barda Nawawi (2008). Bunga Rampai Kebijakan Hukum Pidana Perkembangan Penyusunan Konsep KUHP Baru. Jakarta: Kencana Prenada Media.

Djuned T, (1992), Asas-asas Hukum Adat, Fakultas Hukum Unsyiah.

Kusumaatmaatmadja, Mochtar. (2002). Konsep-konsep hukum dalam Pembangunan, Pusat studi Wawasan Nusantara. Bandung: Alumni.

MD. Moh. Mahfud,(2006). Membangun Politik Hukum, Menegakkan Konstitusi. LP3ES.

Pasal 67 ayat 2 Konsep KUHP 2006

Rato, Dominikus. (2009). Pengantar Hukum Adat. Yogyakarta. LaksBang Pressindo.

Vollenhoven,Cornelis Van. (1981). Penemuan Hukum Adat (De ontdekking van het adatrecht). Terjemahan Koninklijk Instituut voor Taal-, Land-en Volkenkunde (KITLV) bersama Lembaga Ilmu Pengetahuan Indonesia (LIPI). Jakarta. Jambatan.

Wiranata, I Gede AB. (2005). Hukum Adat Indonesia, Perkembangnya dari Masa ke Masa. Bandung: Citra Aditya Bakti. 